\title{
PRZEJRZYSTOŚĆ POLITYKI PIENIĘŻNEJ W TEORII I PRAKTYCE
}

\section{WPROWADZENIE}

Zadaniem każdego banku centralnego jest osiaganie postawionych przed nim celów strategicznych w jak najbardziej skuteczny (efektywny) sposób. Jednym $\mathrm{z}$ warunków wpływających na poprawę efektywności jest jasna i zrozumiała polityka monetarna. Przywiązywanie coraz większej uwagi przez władzę monetarną do prowadzenia niezależnej i odpowiedzialnej polityki spowodowało, że przejrzystość stała się kolejnym, bardzo ważnym instrumentem jakościowym wykorzystywanym przez banki centralne. Ciagłe poprawianie kanału komunikacji, a także ilość i jakość udostępnianych informacji uczestnikom rynku sprawiaja, że władza monetarna stała się bardziej otwarta niektórzy nawet podkreślaja, że przestała być owiana tajemnicą. W ciagu ostatnich 15-20 lat w sposobie komunikowania się z rynkiem nastąpiły zmiany, których nie wszyscy się spodziewali. Obecnie trudno sobie wyobrazić bank, szczególnie ten opierający swoja strategię na bezpośrednim celu inflacyjnym, który nie wykorzystywałby $\mathrm{w}$ swoich działaniach większości z potencjalnie dostępnych instrumentów polityki komunikacyjnej. Lepsze komunikowanie się z otoczeniem poprawia także wiarygodność władzy monetarnej. Odpowiednia komunikacja ma dostarczać rynkowi informacji na temat przekonań, intencji osób podejmujących decyzje w imieniu banku centralnego oraz działań podejmowanych przez władzę monetarną. Ponadto coraz częściej podkreśla się rosnące znaczenie rynku finansowego oraz oczekiwań kształtowanych przez jego uczestników dla prowadzenia polityki pieniężnej. Władza monetarna dysponuje instrumentami, które pozwalaja jej wpływać na stopy krótkoterminowe, natomiast kształtowanie się pozostałych stóp procentowych pozostawia działaniom rynkowym. Decyzje uczestników rynku podejmowane sa pod wpływem oczekiwań dotyczących przyszłych zdarzeń gospodarczych oraz prognoz działań banku centralnego. Zdaniem jednego $\mathrm{z}$ autorów jakość oczekiwań co do przyszłych działań banku centralnego jest funkcją przejrzystości polityki pieniężnej ${ }^{1}$.

W związku z powyższym odpowiednio prowadzona polityka komunikacyjna pomiędzy bankiem centralnym a otoczeniem życia gospodarczego wpływa na

1 J. D. Amato, S. Morris, H. Song Shin, Communication and Monetary Policy, BIS Working Papers 2003, No. 12. 
zwiększenie odpowiedzialności i niezależności władzy monetarnej, wiarygodności w kontekście postrzegania osiągania celów, a w końcowym etapie efektywności prowadzonych działań.

Przejrzystość polityki pieniężnej jest bardzo interesującym i ważnym tematem, ponieważ jednak należy do kategorii jakościowych, jest kategorią trudno mierzalną. Mimo to opracowano metody, za pomocą których można ocenić wpływ transparentnej polityki komunikacyjnej na gospodarkę, rynek finansowy, a przede wszystkim na przewidywalność działań podejmowanych przez bank centralny.

Celem niniejszego artykułu jest przegląd światowego dorobku z ostatnich kilkunastu lat w zakresie problematyki przejrzystości oraz polityki komunikacyjnej banków centralnych zarówno w zakresie zagadnień teoretycznych, jak i prowadzonych badań empirycznych.

\section{POJĘCIE PRZEJRZYSTOŚCI POLITYKI PIENIĘ̇̇NEJ W LITERATURZE ŚWIATOWEJ}

Pojęcie przejrzystości (transparency) odnosi się do ilości i dokładności (precyzji) informacji dostarczanych przez jedną stronę drugiej. Ponieważ z przekazywaniem informacji związany jest problem asymetrii, przejrzystość może być zdefiniowana jako brak asymetrii informacji pomiędzy bankiem centralnym a innymi uczestnikami rynku lub też jako łagodzenie asymetrii poprzez publikowanie ,,prywatnych” informacji przez bank centralny, które są istotne dla prowadzonej polityki ${ }^{2}$. Definicja przejrzystości skupia się na informacji, którą uczestnicy posiadają, oraz na czynności jej dostarczania. Zdaniem M. Goodfrienda ujawnianie przez bank centralny dokładnych informacji redukuje asymetrię i niepewność na rynku. Wynika to $\mathrm{z}$ faktu, że rynek działa zgodnie $\mathrm{z}$ hipotezą rynków efektywnych oraz teorią racjonalnych oczekiwań ${ }^{3}$. Niektórzy autorzy definiuja przejrzystość, wskazując poszczególne cechy, którymi taka polityka musi się charakteryzować. B. Winkler ${ }^{4}$ wymienia wśród nich: 1) otwartość (openness) w ilości i dokładności dostarczanych przez bank centralny informacji, 2) jasność (clarity) w prezentowaniu informacji, ich interpretacji (nie moga one wprowadzać „zamętu” informacyjnego), 3) jednolitość pojmowania (common understanding) - te same informacje i procesy muszą być rozumiane i interpretowane przez dwie strony (bank centralny i pozostałych uczestników gospodarki) w taki sam sposób; jest to konieczny warunek korzystnej komunikacji, a w konsekwencji - przejrzystości polityki pieniężnej, 4) uczciwość, szczerość (honesty) - odnosi się do stopnia, w jakim sposób analizowania, rozumienia poszczególnych informacji przez bank

\footnotetext{
${ }^{2}$ V. Hahn, Transparency in Monetary Policy: A Survey, „IFO Studien” 48, 2002, nr 3, s. 430.

${ }^{3}$ M. Goodfriend, Monetary Mystique: Secrecy and Central Banking, „Journal of Monetary Economics" 17, 1986, nr 1, s. 63-92.

${ }^{4}$ B. Winkler, Which Kind of Transparency? On the Need for Clarity in Monetary Policy Making, ECB Working Papers No. 26, 2000, s. 8.
} 
centralny na potrzeby wewnętrzne banku jest zgodny $\mathrm{z}$ tym prezentowanym na zewnątrz, w komunikacji z otoczeniem.

Ze względu na wielopłaszczyznowość terminu transparentność część autorów wyróżnia różne jej typy (aspekty). P. M. Geraats wprowadza pięć typów przejrzystości:

1) ustawową (political transparency) - odnosi się do otwartości w zakresie celów, które powinna osiagnąć władza monetarna. Obejmuje ona swym zasięgiem dokładne określenie priorytetowego celu polityki pieniężnej wraz z ilościowym jego oznaczeniem. Ponadto ważne jest tu także istnienie formalnych umów, ustaw określających związki banku centralnego z rządem, co wpływa na stopień niezależności banku centralnego. Uniemożliwia to nadmierną ingerencję polityków w działania poodejmowane przez komitet monetarny;

2) ekonomiczną (economic transparency) - odnosząca się do informacji gospodarczych, które są następnie podstawą podejmowania decyzji przez bank centralny. Ten typ przejrzystości obejmuje zdaniem Geraats udostępnianie: a) danych makroekonomicznych, b) modelu wykorzystywanego do konstruowania prognoz, a także dokonywania ocen wpływu podejmowanych decyzji przez bank centralny, c) wewnętrznych prognozy, na podstawie których bank centralny podejmuje swoje decyzje;

3) proceduralną (procedural transparency) - określa ona sposób, w jaki podejmowane sa decyzje przez komitety monetarne. Obejmuje ona strategię oraz zasady, którymi kieruje się bank centralny, a także określa, w jaki sposób te decyzje sa osiagane przez publikację protokołu z posiedzeń komitetu monetarnego (tzw. minutes) oraz rozkładu głosów (voting records);

4) polityczną (policy transparency) - dotyczy ogłoszenia podjętych decyzji. Obejmuje ona swoim zasięgiem ogłoszenie decyzji, wyjaśnianie ich, a także wskazanie na przyszłe potencjalne decyzje, które mogą być podjęte w określonych warunkach gospodarczych i zewnętrznych;

5) operacyjną (operational transparency) - zwiazzana jest ona $\mathrm{z}$ publikowaniem oceny skutków prowadzonej polityki pieniężnej, wdrażaniem decyzji banku centralnego w życie oraz obserwowaniem i analiza nieoczekiwanych zdarzeń, które moga zaburzyć mechanizm transmisji polityki pieniężnej ${ }^{5}$.

Każdy z typów przejrzystości spełnia określone funkcje. Odnosząc się do powyższych pięciu typów, S. C. Eijffinger i P. M. Geraats ${ }^{6}$ wskazuja, że przejrzystość ustawowa, ekonomiczna oraz operacyjna moga przyczyniać się do wzmacniania wiarygodności banku centralnego w dążeniu do osiagnnięcia głównego celu: stabilności cen. Przejrzystość proceduralna może poprawiać jakość procesu decyzyjnego, a polityczna może zwiększać efektywność w kształtowaniu się stóp procentowych.

${ }^{5}$ S. C. Eijffinger, P. M. Geraats, How Transparent Are Central Banks?, 2005, http://www.econ. cam.ac.uk/faculty/geraats/tpindex.pdf, s. 7-11.

${ }^{6}$ Ibidem, s. 5. 


\section{NARZEDZIA I FORMY POLITYKI KOMUNIKACYJNEJ}

W celu zwiększania przejrzystości prowadzonej polityki pieniężnej strategia informacyjna banku centralnego powinna dążyć do zapewnienia równowagi pomiędzy otwartością polityki banku centralnego a prostotą przekazu ${ }^{7}$. Z jednej strony ilość przekazywanych informacji przez władze monetarne nie może być zbyt duża, by nie zarzucać rynku masa nieistotnych danych. Sposób przekazywania tych informacji nie może być za bardzo skomplikowany, aby niepotrzebnie nie gmatwać ani nie zamazywać istoty przekazu. Niewłaściwe jest jednak z drugiej strony także stosowanie przez bank centralny skomplikowanych procedur i metod analitycznych na własny użytek, a na zewnątrz prezentowanie ich $\mathrm{w}$ zbyt uproszczony sposób. Niezachowanie równowagi (w którąkolwiek ze stron) prowadzi do mniejszej przejrzystości.

\section{Narzędzie polityki komunikacyjnej banku centralnego}

W jednej z bardzo ważnych prac z ostatnich lat, które poruszają temat polityki komunikacyjnej banków centralnych, autorzy wskazują, że bank centralny komunikuje się z otoczeniem w czterech głównych obszarach, które dotyczą: 1) celów i strategii, 2) motywów podejmowania poszczególnych decyzji, 3) danych ekonomicznych, 4) przyszłych decyzji ${ }^{8}$. Te oraz inne narzędzia wspomagające komunikację zostały przedstawione poniżej.

Jednym z bardzo ważnych narzędzi jest wyraźne określenie celu polityki pieniężnej i publiczne jego przedstawianie. Wprowadzenie zasady ogłaszania w stosownym dokumencie długoterminowego celu polityki pieniężnej powoduje, że uczestnicy życia gospodarczego wiedzą, do czego bank centralny dąży, a to pozwoli im zrozumieć decyzje przez niego podejmowane. Ponadto bank centralny może także wyznaczać cele krótkoterminowe, które maja służyć osiagnięciu celu długoterminowego. Znajomość celu polityki monetarnej pozwala na rozliczanie banku centralnego $\mathrm{z}$ wykonywanego mandatu oraz pomaga w zakotwiczeniu oczekiwań inflacyjnych ${ }^{9}$. Zdaniem wielu autorów dokładne, ilościowe określenie celu poprawia przejrzystość prowadzonej przez bank centralny polityki.

Najważniejsze długookresowe cele polityki monetarnej powinny być zapisane $\mathrm{w}$ strategii. Jest to dokument najczęściej tworzony na kilka lub kilkanaście lat, w którym szczegółowo przedstawia się, w jaki sposób oraz za pomoca jakich narzędzi będzie prowadzona polityka monetarna zmierzająca do osiagnnięcia celu długoterminowego. Warto zaznaczyć, że dokument ten powi-

${ }^{7}$ K. Szeląg, Strategia jednolitej polityki pieniężnej $w$ strefie euro - kluczowe elementy $i$ zasady, Narodowy Bank Polski, Materiały i Studia, z. 162, Warszawa 2003, s. 32.

${ }^{8}$ A. Blinder et al., Central Bank Communication and Monetary Policy: A Survey of Theory and Evidence, ECB Working Paper Series No. 898, 2008, s. 18.

${ }^{9}$ G. Wesołowski, P. Żuk, Rola komunikacji banków centralnych z otoczeniem, NBP, Warszawa 2011, s. 3. 


\section{Schemat 1}

Instrumenty polityki komunikacyjnej banku centralnego

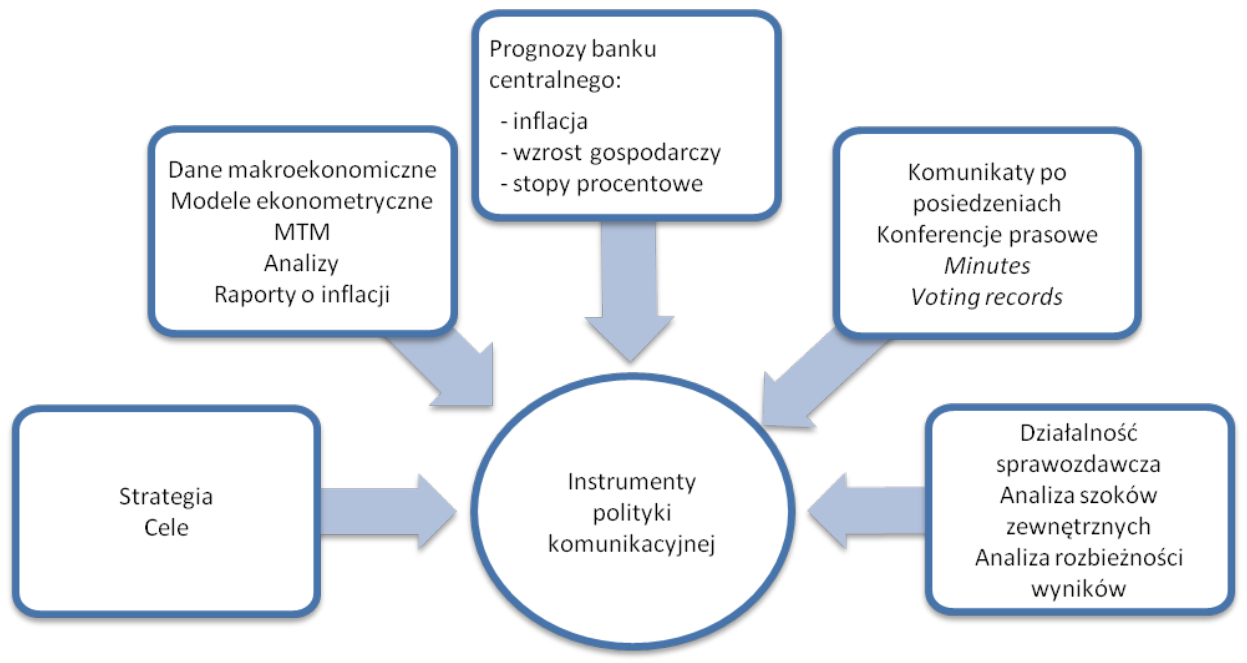

Źródło: opracowanie własne.

nien zyskać ogólną akceptację wszystkich uczestników życia gospodarczego, szczególnie rządu.

Bardzo istotnym wyznacznikiem przejrzystości jest systematyczna publikacja danych i analiz wykorzystywanych przez bank centralny $\mathrm{w}$ trakcie podejmowania decyzji. Dotyczy to zarówno samych danych statystycznych, jak i raportów przedmiotowo-tematycznych. Banki centralne starają się zwiększać przejrzystość przez publikowanie analiz, w których przedstawiają swoje działania na tle sytuacji gospodarczej, osiągniętych celów, szczególnie ważnych dla przyszłych poczynań. Wśród tych publikacji wyróżnia się m.in. kwartalne i roczne raporty o inflacji oraz miesięczne biuletyny statystyczne. Raport o inflacji zawiera bieżąca ocenę procesów inflacyjnych i czynników wpływających na zmiany wskaźnika cen w danym kraju, opis polityki pieniężnej prowadzonej w ciagu ostatniego okresu, projekcję inflacyjną na przyszłe lata. Wspomniana projekcja inflacji jest, oprócz prognozy wzrostu gospodarczego, bardzo ważnym instrumentem polityki komunikacyjnej banków centralnych. W ostatnich latach dużo uwagi zaczęto poświęcać możliwościom informowania o przyszłych działaniach komitetu monetarnego przez publikację ścieżki przyszłych stóp procentowych przez bank centralny. Jest to instrument używany obecnie przez nieliczne banki centralne. Zwolennicy publikacji ścieżki stóp procentowych podkreślająjej pozytywny wpływ na kształtowanie się oczekiwań rynkowych, natomiast przeciwnicy uważają, że opublikowana prognoza stóp procentowych jest zobowiązaniem banku centralnego, a uczestnicy rynku nie traktują tej prognozy jako pewnego scenariusza, który może się spełnić przy zaistnieniu konkretnych okoliczności gospodarczych. Pozytywny wpływ tego narzędzia na skuteczność prowadzonej polityki pieniężnej nie został w pełni 
potwierdzony ${ }^{10}$. Choć są także badania przeprowadzone na przykładzie Banku Nowej Zelandii i Banku Norwegii, które wskazuja na pozytywny efekt jego zastosowania.

Wśród instrumentów polityki komunikacyjnej należy także wyróżnić wyjaśnianie mechanizmu transmisji impulsów polityki pieniężnej (MTM). W tym celu bank centralny powinien objaśniać w dokumentach strategicznych i publikowanych artykułach działanie MTM i charakteryzować wpływ podejmowanych decyzji o zmianie stóp procentowych na stopy rynkowe, inflację czy produkcję. Ponadto ważne jest odpowiednie uzasadnienie decyzji i działań podejmowanych przez władzę monetarną oraz przyczyn odchyleń od założonych lów.

Poza tym na rzecz poprawy przejrzystości prowadzonej polityki pieniężnej składają się także wywiady członków komitetu monetarnego z mediami, ekonomistami, analitykami bankowymi czy też ich udziały w konferencjach tematycznych.

Każdy bank centralny, a ściśle mówiąc: wybrane ciała decyzyjne, podejmuje decyzje, na które co miesiąc oczekuje cały rynek finansowy. Dlatego bardzo ważnym instrumentem poprawiającym przejrzystość polityki pieniężnej są komunikaty poposiedzeniowe, w których bank centralny oficjalnie ogłasza podjętą decyzję. Kolejną determinantą przejrzystości są konferencje prasowe po każdym posiedzeniu władz monetarnych, na których ogłaszane sa jej decyzje wraz ze stosownym komentarzem. Natychmiastowe przekazanie decyzji banku wraz z jej umotywowaniem oraz publikacją komunikatu na stronie internetowej zapewniają odpowiednią komunikację ze społecznością. Wśród instrumentów zmniejszających źródło asymetrii znajduje się także publikowanie protokołów $\mathrm{z}$ posiedzeń banku centralnego (minutues) oraz rozkładu głosów (voting records). Te informacje mogá dostarczać rynkowi wiedzy na temat motywów, które wpłynęły na podjęcie decyzji, ich związku z osiągnięciem celu oraz o poglądach członków komitetu monetarnego. P. Gerlach-Kristen ${ }^{11}$ wskazuje, że publikacja wyników głosowania pomagała rynkom finansowym przewidywać decyzje Banku Anglii. M. J. M. Neumann także stwierdza, że znajomość rozkładu głosowania może dostarczać uczestnikom rynku informacji na temat możliwych przyszłych decyzji władz monetarnych ${ }^{12}$. Publikowanie rozkładu głosów jako instrumentu zwiększającego przejrzystość jest jednak przez niektórych uważane za wątpliwe. Z jednej strony publikowanie informacji, jak głosowali poszczególni członkowie, może uniemożliwiać naciski polityczne, ale z drugiej - można wnioskować, iż skoro wygłaszający opinię wie, że będzie ona opublikowana, nie jest w pełni szczery. Zarówno prace naukowe, jak i stosowane praktyki nie sa w tym obszarze jednoznaczne. FED oraz Riksbank publikuja

${ }^{10}$ A. Sławiński (red.), Polityka pieniężna, C. H. Beck, Warszawa 2011, s. 147; M. Brzoza-Brzezina, Korzyści z publikacji projekcji makroekonomicznych i ścieżki stóp procentowych w Polsce, „Bank i Kredyt” 2008, nr 12.

${ }^{11}$ P. Gerlach-Kristen, Is the MPC's Voting Record Informative about Future UK Monetary Policy, „Scandinavian Journal of Economics” 106, 2004, nr 2, s. 312.

${ }^{12}$ M. J. M. Neumann, Transparency in Monetary Policy, ,Atlantic Economic Journal” 30, 2002, nr 4 (December), s. 358. 
rozkład głosów wraz z decyzją odnośnie do poziomu stóp podstawowych od razu po posiedzeniu komitetu monetarnego, natomiast Bank Anglii przedstawia, w jaki sposób głosowali poszczególni członkowie, dopiero dwa tygodnie po zakończonym spotkaniu. W wypadku tych przykładów można podjąć próbę oszacowania możliwego wpływu publikacji rozkładu głosów na zmienność cen na rynku finansowym. Z kolei Narodowy Bank Polski publikuje dane na temat głosowania dopiero 6 tygodni po zakończonym posiedzeniu, co w praktyce uniemożliwia sprawdzenie, czy w przeszłości można było prognozować przyszłe decyzje Rady Polityki Pieniężnej (RPP) na podstawie znanego rozkładu głosów. Europejski Bank Centralny nie dostarcza rynkowi rozkładu głosów w ogóle, a argumentuje to tym, że decyzje podejmowane są kolegialnie, więc taka informacja byłaby dla rynku bezwartościowa.

Przejrzystość komunikacji umacnia także działalność sprawozdawcza banku centralnego. Składa się na nią przygotowywanie i przedstawianie władzy ustawodawczej sprawozdań $\mathrm{z}$ jego działalności. Dokument ten powinien zawierać informacje na temat decyzji podejmowanych przez władzę monetarna w danym okresie sprawozdawczym, stosowanych instrumentów w określonym otoczeniu gospodarczym, a przed wszystkim nie może w nim zabraknąć oceny stopnia osiagnnięcia postawionych przed bankiem centralnym celów. W wypadku rozbieżności planów z efektami należy dokonać szczegółowej analizy, której celem jest wskazanie na przyczyny takiej sytuacji. Analiza szoków zewnętrznych oraz rozbieżności pomiędzy zaplanowanymi działaniami a uzyskanymi efektami jest bardzo ważnym elementem pełnej polityki komunikacyjnej banku centralnego.

Wszystkie wymienione czynniki zwiększaja przejrzystość polityki pieniężnej. Pojawia się w związku z tym pytanie, czy wdrożenie w życie wszystkich powyższych działań sprawi, że polityka monetarna będzie perfekcyjnie przejrzysta (perfect transparency). Okazuje się, że w praktyce nie jest możliwe osiagnięcie pełnej przejrzystości, ponieważ bank centralny nie jest $\mathrm{w}$ stanie publikować wszystkich raportów, analiz, dyskusji, które miały miejsce, a które to są podstawą podejmowanych decyzji. Zjawisko to nazywane jest w niektórych pracach naturalnym ograniczeniem przejrzystości (natural limits to transparency $)^{13}$. Dlatego też w praktyce należy dokonywać selekcji informacji, które będą publicznie dostępne.

Bank centralny dysponuje wielomo instrumentami, które mogą poprawiać sposób komunikowania się z otoczeniem - od podania do wiadomości publicznej strategii i celu polityki pieniężnej aż do publikacji rozkładu głosów podczas posiedzenia komitetu monetarnego czy też publikacji ścieżki przyszłych stóp procentowych.

Poza ilością dostępnych oraz stosowanych narzędzi dla przejrzystości polityki pieniężnej ważny jest także tzw. timing, czyli wybór odpowiedniego momentu, w którym rynek zapoznaje się z nowymi komunikatami lub oświadczeniami. Aby polityka monetarna była przejrzysta, bank centralny powinien ujawniać informacje w odpowiednim czasie, tak szybko, jak jest to możliwe.

${ }^{13}$ H. Remsperger, A. Worms, Transparency in Monetary Policy, CFS Working Papers No. 1999/16, 1999 , s. 10 . 


\section{Forma komunikacji}

Bank centralny może komunikować się z rynkiem na wiele sposobów. W zależności od stosowanej strategii każdy z banków wybiera swój własny sposób na dostarczanie rynkowi finansowemu stosownych informacji. Jednym z wyborów, przed którym stoi władza monetarna, jest podjęcie decyzji, kto po stronie banku centralnego będzie „nadawcą" komunikatów - czy będą to sygnały wysyłane przez komitet, czy też przez indywidualnych członków. W tym miejscu warto zwrócić uwagę, że obecnie większość banków podejmuje swoje decyzje za pośrednictwem komitetów, z tym że - jak zauważa A. Blinder komitety monetarne w poszczególnych krajach moga przyjmować różne kształty i rozmiary ${ }^{14}$. I tak wyróżnia on trzy typy komitetów: indywidualistyczny (np. Bank Anglii), prawdziwie kolegialny (np. EBC), autokratycznie kolegialny (np. FED za czasów Alana Greenspana). W zależności od stosowanej formy odmienność poglądów pomiędzy poszczególnymi członkami może być inaczej odbierana przez otoczenie. W wypadku kolegialnego podejścia różnorodność poglądów będzie osłabiać przejrzystość i efektywność polityki.

Przekazywanie informacji przez komitet monetarny najczęściej odbywa się po posiedzeniach, na których podejmowane sa decyzje w sprawie określenia poziomu głównej stopy procentowej. W zależności od kraju proces przekazywania tych informacji się różni. W części krajów po zakończeniu posiedzenia publikuje się krótką informację na temat podjętej decyzji, następnie odbywa się konferencja prasowa, a na dalszym etapie publikowane są protokół z posiedzenia oraz rozkład głosów. Należy podkreślić, że przekazywanie wszelkich informacji przez komitet monetarny lub w jego imieniu odbywa się zawsze według określonych reguł w ściśle określonym, zaplanowanym wcześniej momencie. Uczestnicy rynku przygotowani są na te komunikaty.

$\mathrm{Na}$ korzyść komunikowania się z rynkiem za pośrednictwem członków komitetu przemawia większa swoboda $\mathrm{w}$ zakresie czasu przekazu oraz jego formy. Szczególnie w wypadków nieoczekiwanych zmian warunków gospodarczych, które są istotne dla polityki monetarnej, rola poszczególnych członków komitetu monetarnego jest nieoceniona. Moga oni bardzo szybko zareagować na nowe informacje. W sytuacjach zwiększonej niepewności bank centralny za pośrednictwem swoich przedstawicieli może dostarczać uczestnikom życia gospodarczego dodatkowych informacji. Okazjonalne przemówienia lub wywiady poszczególnych członków pomiędzy oficjalnymi posiedzeniami komitetu monetarnego są sposobem na bardziej elastyczne przekazywanie zmian w poglądach banku centralnego. Należy jednak zauważyć, iż z komunikowaniem się banku centralnego za pośrednictwem poszczególnych członków indywidualnie wiąże się także niepewność ${ }^{15}$. Kiedy różni członkowie komitetu monetarnego przekazują odmienne informacje - celowo lub nie - wysyłane sa sprzeczne sygnały, które zwiększają niepewność na rynku finansowym. Jak

${ }^{14}$ A. Blinder, Talking about Monetary Policy: The Virtues (and Vices?) of Central Bank Communication, BIS Working Paper No. 274, 2009, s. 8.

${ }^{15}$ A. Blinder et al., op. cit., s. 37. 
zauważył Blinder, bank centralny, który mówi wieloma różnymi głosami, to tak jakby nie mówił wcale.

Blinder i inni ${ }^{16}$ podkreślaja jednak, że rynek adaptuje się do stylu komunikowania się banku centralnego - dostosowuje się do niego. Kiedy bank centralny charakteryzuje się rozproszoną komunikacją, uczestnicy rynku próbują zidentyfikować jednego, kilku kluczowych członków i tylko do ich wypowiedzi przykładają większą wagę.

\section{PRZEGLĄD WYBRANYCH BADAŃ DOTYCZĄCYCH PRZEJRZYSTOŚCI POLITYKI PIENIĘŻNEJ}

W ciagu ostatnich 15-20 lat tematyka przejrzystości polityki pieniężnej była bardzo często poruszana w pracach naukowych. Poniżej dokonano zestawienia najważniejszych, zdaniem autorki, prac poświęconych wpływowi polityki komunikacyjnej banku centralnego na zachowanie się uczestników rynku finansowego. Opisywane badania zostały pogrupowane w kilka kategorii: 1) wpływ komunikacji banku centralnego na rynek finansowy w krótkim terminie, który można analizować w kontekście przewidywalności przyszłych decyzji władzy monetarnej, wyboru odpowiedniej formy przekazywania informacji, skonstruowania przekazu zapewniającego wysoką jakość i odpowiednia jasność (czytelność) publikowanych dokumentów, 2) wpływ komunikacji banku centralnego na rynek finansowy w długim terminie, który pozwala wnioskować na temat kształtowania się oczekiwań inflacyjnych, 3) porównywanie stopnia przejrzystości pomiędzy różnymi gospodarkami za pomocą indeksów mierzących stopień transparentności prowadzonej polityki.

Ze względu na obszerność wymienionych powyżej obszarów badawczych w niniejszej pracy opisane zostaną tylko wybrane. Wpływ polityki komunikacyjnej na kształtowanie się oczekiwań inflacyjnych zostanie tu pominięty.

\section{Wpływ komunikacji banku centralnego na reakcje rynku finansowego w krótkim terminie}

Jedną z metod stosowanych przez badaczy do oceny wpływu przejrzystości polityki pieniężnej na rynek finansowy jest tzw. efekt ogłoszeń (announcement effect). Metoda ta polega na badaniu reakcji cen aktywów finansowych na przekazywane przez bank centralny komunikaty.

W świetle prowadzonych badań można wyróżnić dwa typy zdarzeń, które podlegały identyfikacji oraz pomiarowi:

- regularne komunikaty przedstawiane rynkowi zgodnie $\mathrm{z}$ zaplanowanym harmonogramem (np. dotyczące decyzji podjętych w sprawie poziomu głównych stóp procentowych) oraz

- nieregularne oświadczenia, takie jak: wywiady, przemówienia na tematy bieżące, a także ewentualnie dotyczące przyszłych działań banku centralnego.

${ }^{16}$ Ibidem, s. 38. 
W tym wypadku trudniejsza jest identyfikacja określonego zdarzenia i zbadanie jego wpływu na inne zmienne.

Autorzy podejmujący się powyższych badań poszukują odpowiedzi na kilka ważnych pytań: 1) Czy konkretny, wysłany przez bank centralny sygnał zawiera w sobie nowe informacje?, 2) $\mathrm{Z}$ jaką siłą rynek reaguje na publikowane informacje?, 3) Czy zmiany cen instrumentów finansowych następuja w odpowiednim kierunku do przekazanego komunikatu?, 4) Czy w dniu ogłoszenia komunikatu zaplanowanego czy też niespodziewanego zaobserwowano wyższą zmienność cen aktywów?, 5) Czy zwiększona zmienność cen na rynku finansowym wywołana określonym przekazem jest efektem nowych informacji i dzięki temu zmniejsza się niepewność na rynku, czy wręcz odwrotnie wprowadza dodatkowy chaos informacyjny?

Oczywiście należy sobie zadać pytanie, czy badając wpływ wysłanego komunikatu przez bank centralny w danym dniu, mamy pewność, że to ten przekaz wywołał reakcję rynku, czy przypadkiem nie jest to działanie innych czynników, takich jak np. nagłe, nieoczekiwane zmiany w poziomie innych zmiennych makroekonomicznych. $\mathrm{O}$ ile $\mathrm{w}$ wypadku regularnych, zaplanowanych komunikatów wysyłanych przez władzę monetarną o konkretnej godzinie łatwiej jest ten impuls wyodrębnić, o tyle w wypadku sporadycznych przemówień czy wywiadów poszczególnych członków komitetów monetarnych, mających miejsce w różnym czasie i formie, jest to znacznie trudniejsze.

\subsection{Przewidywalność przyszłych decyzji banku centralnego}

W niniejszym opracowaniu rozróżnia się postrzeganie przewidywalności polityki pieniężnej w krótkim i długim terminie. Przewidywalność krótkoterminowa jest definiowana jako zdolność do antycypowania przyszłych decyzji banku centralnego w stosunkowo krótkim okresie. Podstawą znacznej części badań była analiza zmiany cen aktywów finansowych w okolicach dnia ogłoszenia komunikatu przez komitet monetarny. Szczególną uwagę skupiano na reakcji rynku na tzw. zaskoczeniu, czyli zmianie nieoczekiwanej przez rynek.

Najwięcej prac poświęcono reakcjom rynku amerykańskiego na decyzje FED. T. Cook i T. Hahn badali związek pomiędzy zmianą w stopie funduszy federalnych a zmianą w krótko- i długoterminowych stopach procentowych w dniu podjęcia decyzji przez FED w latach 1974-1979 ${ }^{17}$. Analiza regresji wskazała, że najbardziej na decyzje FED reagował krótki odcinek krzywej dochodowości, a im termin zapadalności był bardziej odległy, tym reakcje te były mniej istotne. Drugie badanie przeprowadzone przez Cooka i Hahna różniło się momentem, w którym badali oni reakcje stóp rynkowych: analizowali oni reakcje rynkowe na dwa dni przed i jeden dzień przed zmiana, w dniu zmiany oraz w dzień i dwa dni po zmianie stopy przez FED. Okazało się, że największe reakcje tych trzech rodzajów stóp procentowych widoczne były $\mathrm{w}$ dniu ogłoszenia tej zmiany i dzień po jej ogłoszeniu. Świadczyło to o niepewności

${ }^{17}$ T. Cook, T. Hahn, The Effect of Changes in the Federal Funds Rate Target on Market Interest Rates in the 1970s, Federal Reserve Bank of Richmond, Working Papers No. 88-4, 1988. 
rynku co do wielkości zmian dokonywanych przez FED i niepełnej przewidywalności przyszłych decyzji banku centralnego. K. N. Kuttner ${ }^{18}$ przy wykorzystaniu stopy kontraktów futures na stopę funduszy federalnych szacował wpływ oczekiwanej i nieoczekiwanej decyzji FED na reakcje rynkowych stóp zwrotu. Uzyskane przez niego wyniki jasno wskazały, że rynek reaguje znacząco tylko na nieoczekiwane decyzje banku centralnego. Inne badania prowadzone na rynku amerykańskim pozwalają zaobserwować zmiany w reakcjach rynku na decyzje FOMC wywołane poprawa polityki komunikacyjnej. Praca W. Poole'a i R. Rasche'a ${ }^{19}$ dowodzi, że w wyniku zmian wprowadzonych w lutym 1994 r. (rozpoczęcie ogłaszania decyzji w sprawie poziomu stopy federal funds w dniu jej podjęcia) wartość elementu zaskoczenia decyzjami monetarnymi się zmniejszała.

A. Haldan i V. Read analizowali reakcje stóp krótkoterminowych oraz długoterminowych, a następnie weryfikowali je w kontekście przejrzystości i wiarygodności polityki monetarnej ${ }^{20}$. Badano gospodarkę Stanów Zjednoczonych, Wielkiej Brytanii, Niemiec oraz Włoch. Przytoczone rezultaty wskazują, że w Stanach Zjednoczonych i w Niemczech wysokość parametru szacowanej regresji $\left(\gamma_{j}\right)$ na krótkim końcu krzywej dochodowości (świadczący o stopniu przejrzystości polityki pieniężnej) była znacznie niższa niż w wypadku Wielkiej Brytanii i Włoch, co oznacza większą przejrzystość i przewidywalność prowadzonej polityki pieniężnej.

K. Bernoth i J. von Hagen ${ }^{21}$ przeprowadzili badanie, którego jednym z celów było analizowanie wpływu decyzji Europejskiego Banku Centralnego na kształtowanie się stóp kontraktów futures na EURIBOR. Przewidywalność decyzji władz monetarnych badali oni, porównując zmienności stóp futures w dniu ogłoszenia decyzji oraz w pozostałych dniach w okresie styczeń 1999 marzec 2002. Miara badania ,zaskoczenia” rynku decyzjami banku centralnego była zmienność 3-miesięcznych kontraktów futures $\mathrm{w}$ dniu ogłoszenia informacji. Okazało się, że średnia zmienność stóp futures w dniu posiedzenia była prawie dwa razy większa niż w innych dniach, co było spowodowane zmianami oficjalnych stóp procentowych. Analiza zmiany bezwzględnego błędu prognozy wykazała, że nie można stwierdzić, iż z czasem decyzje banku centralnego sa coraz lepiej antycypowane i poprawiaja prognozy dotyczące przyszłych stóp procentowych.

B. Wilhelmsen i A. Zaghini ${ }^{22}$ oceniali zdolność uczestników rynku do przewidywania decyzji komitetów monetarnych EBC oraz 13 banków z innych

${ }^{18}$ K. N. Kuttner, Monetary Policy Surprise and Interest Rates: Evidence from the FED Funds Futures Market, ,Journal of Monetary Economics” 47, 2001, nr 3.

${ }^{19}$ W. Poole, R. Rasche, The Impact of Changes in FOMC Disclosure Practices on the Transparency of Monetary Policy: Are Markets and the FOMC Better „Synched”, „Federal Reserve Bank of St. Louis Review" 85, 2003, nr 1, s. 1-10.

${ }^{20}$ A. Haldan, V. Read, Monetary Policy Surprises and the Yield Curve, Bank of England, Working Papers No. 106, 2000.

${ }^{21}$ K. Bernoth, J. von Hagen, The Performance of the Euribor Futures Market: Efficiency and the Impact of ECB Policy Announcements, Federal Reserve Bank of New York, Workshop Monetary Policy and the Money Market, 2003.

${ }^{22}$ B. Wilhelmsen, A. Zaghini, Monetary Policy Predictability in the Euro Area: An International Comparison, Working Paper Norges Bank No. 2005/07. 


\section{Wykres 1}

Reakcje rynku pieniężnego na decyzje komitetów monetarnych

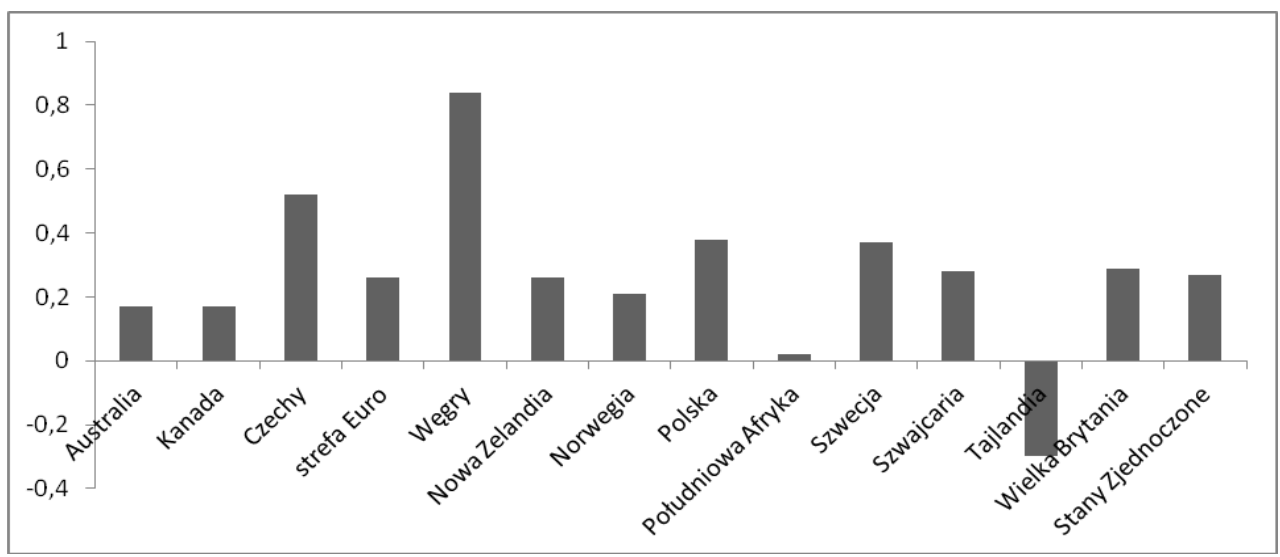

Wartość dla Południowej Afryki okazała się nieistotna statystycznie

Źródło: opracowanie własne na podstawie B. Wilhelmsen, A. Zaghini, op. cit.

krajów w okresie 1999 - kwiecień 2004. Uzyskane wyniki pozwoliły autorom na wyciągnięcie dwóch bardzo ważnych wniosków. Po pierwsze, zasięg oraz zmienność stawek na rynku pieniężnym sugerują, że dzień podejmowania i ogłaszania decyzji przez władzę monetarną jest szczególnym dniem dla rynków finansowych. Po drugie, jak wskazuje poniższy wykres, wartość parametru szacowanego równania (regresja analizuje reakcje rynku na decyzje banków centralnych) dowodzi, że przewidywalność polityki pieniężnej EBC była porównywalna z polityką FED oraz Banku Anglii.

A. Holmsen i inni ${ }^{23}$ przeprowadzili badanie wpływu przejrzystości polityki pieniężnej na przewidywalność decyzji na rynku norweskim. Wybrany przez nich do badania horyzont badawczy pokrywał się z okresem istotnych zmian dokonywanych w polityce komunikacyjnej banku centralnego. Uzyskane wyniki potwierdziły pozytywny wpływ przejrzystości polityki pieniężnej na zmniejszenie zmienności stóp rynkowych w dniu posiedzeń komitetu monetarnego, co dowodzi, że właściwa komunikacja poprawia właściwe odczytywanie intencji banku centralnego $\mathrm{w}$ zakresie przewidywalności jego decyzji.

Analizę dla rynku polskiego w okresie: listopad 1995 - maj 1998 oraz czerwiec 1998 - wrzesień 2000 przeprowadził J. Zieliński ${ }^{24}$. Jej wyniki dowodza, że przejście do strategii BCI nie poprawiło znacznie wartości parametru regresji, świadczącego o stopniu przejrzystości polityki pieniężnej.

\footnotetext{
${ }^{23}$ A. Holmsen et al., Communicating Monetary Policy Intentions: The Case of Norges Bank, Norges Bank Working Paper 2008.

24 J. Zieliński, Transparency of Monetary Policy in Poland: Yield Curve Responses to Changes in Official Interest Rates, National Bank of Poland, Paper No. 20, Warsaw 2001.
} 
Wielkości współczynnika zmiennej mierzącej reakcję na zmiany stóp NBP nie różniły się od siebie istotnie przed i po 1998 r. Choć wartości te były niższe po wdrożeniu BCI niż w wypadku okresu poprzedniego, ale porównanie tych wyników z rynkiem amerykańskim lub niemieckim uwidoczniło znaczną różnicę. Na podstawie uzyskanych wyników autor badania stwierdził, że strategia komunikowania się NBP była ciągle niedoskonała i nie dostarczała uczestnikom rynku wystarczających informacji na temat przyszłych działań władz pieniężnych. Wśród kolejnych prac dotyczących rynku polskiego są m.in. prace D. Serwy ${ }^{25}$, M. Rozkruta ${ }^{26}$ oraz J. Janeckiego ${ }^{27}$. Wspomniane badania prowadzone były w dłuższym horyzoncie czasowym, co umożliwiło uwzględnienie bardzo istotnych zmian w polityce komunikacyjnej NBP.

\subsection{Wpływ formy przekazywania komunikatów na rynek finansowy}

Opisywane powyżej badania wyraźnie wskazuja, że działania podejmowane przez władzę monetarna istotnie wpływaja na kształt krzywej dochodowości. Istnieje także grupa analiz, która potwierdza, że nie tylko działania, lecz także słowa i forma, w jakiej są one przekazywane, są ważne dla uczestników gospodarki.

Opisali to D. Kohn i B. Sack ${ }^{28}$. Podstawa ich badania były wypowiedzi przedstawicieli banku centralnego w latach 1989-2003, podzielone na trzy grupy komunikatów: oświadczenia wydawane przez FOMC (142 zdarzenia), oświadczenia wygłaszane przez Greenspana przed Kongresem (66 zdarzeń) oraz przemówienia Greenspana (123 zdarzenia). Przeprowadzona analiza wykazała, że forma, w jakiej przekazywane sa informacje, jest istotnym czynnikiem wywołującym określone reakcje rynkowe. Oświadczenia wydawane przez FOMC okazały się znacząco wpływać na rynkowe stopy procentowe o krótkim i średnim terminie zapadalności, z tym że stopy o najkrótszych terminach bardziej reagowały na to, co bank centralny robi, niż na to, co komunikuje. Z kolei zeznania Greenspana przed Kongresem wywoływały szczególnie silne reakcje na długim odcinku krzywej dochodowości ${ }^{29}$. W celu wyjaśnienia zauważonych reakcji rynku na odmienne formy komunikowania się autorzy badań wyróżnili dwa komponenty w komunikacji FED, które ich zdaniem powodowały takie zachowania rynku: 1) policy inclination komunikaty niosące informacje dotyczące najbliższych działań i intencji FOMC; 2) economic outlook - za pomoca tego typu wiadomości bank centralny sygnalizuje rynkowi zmianę swojej oceny perspektyw gospodarczych, która będzie podstawą decyzji odłożonych w czasie. Zmiany stóp krótkoterminowych sa,

${ }^{25}$ D. Serwa, M. Szymańska, Reakcje rynków finansowych na szoki w polityce pieniężnej, „Bank i Kredyt" 2004, nr 6.

${ }^{26}$ M. Rozkrut, It's Not Only What Is Said, It's also Who the Speaker Is. Evaluating the Effectiveness of Central Bank Communication, National Bank of Poland Working Paper, No. 47, 2008.

${ }_{27}$ J. Janecki, Reakcja rynkowych stóp procentowych na zmiany stopy procentowej banku centralnego, NBP, 2011.

${ }^{28}$ D. Kohn, B. Sack, Central Bank Talk: Does It Matter and Why?, 2003, http://www. federalreserve.gov/pubs/feds/2003/200355/200355pap.pdf.

${ }^{29}$ Ibidem, s. 21-22. 
zdaniem Kohna i Sacka ${ }^{30}$, wywołane przede wszystkim działaniami banku centralnego, a w związku $\mathrm{z}$ tym zależą od komponentu policy inclination, natomiast ruchy stóp jednorocznych i dwuletnich znajdują się pod silnym wpływem komponentu economic outlook.

Powyższą metodologię w swoim badaniu wykorzystali także R. Reeves i M. Sawicki ${ }^{31}$. Analizowali oni wpływ publikowanych oficjalnych komunikatów wysyłanych przez Bank Anglii od czerwca 1997 r. do grudnia 2004 r. Badaniu poddali cztery rodzaje form komunikowania się z rynkiem: publikację minutes oraz kwartalnych raportów o inflacji, oświadczenia członków komitetu monetarnego oraz ich wystapienia przed parlamentem. Na podstawie danych dziennych i śróddziennych badali oni zmiany $\mathrm{w}$ poziomie zmienności cen aktywów po publikacji określonych informacji. Uzyskane przez nich rezultaty dowiodły, że przekazywane przez Bank Anglii informacje mają wymierny wpływ na ceny aktywów finansowych (szczególnie na rynku instrumentów krótkoterminowych). Publikacja minutes oraz raportów o inflacji wywoływała na rynku znaczną zmienność cen, natomiast tego typu reakcji nie zauważono w wypadku pozostałych analizowanych form komunikacji.

Sposób podejmowania i przedstawiania decyzji przez komitety monetarne wpływa na efektywność polityki komunikacyjnej banku centralnego. W związku z tym wybór odpowiedniej a zarazem optymalnej strategii jest niezmiernie istotny. W celu wykazania ważności tej tezy M. Ehrmann i M. Fratzscher ${ }^{32}$ przeprowadzili badanie, w którym podjęli próbę określenia wpływu wywiadów oraz przemówień członków komitetów monetarnych Rezerwy Federalnej, Banku Anglii oraz EBC na kształtowanie się cen wybranych aktywów finansowych. Swoim badaniem sprawdzali, czy bardziej efektywna forma komunikacji poprawia zdolność rynku finansowego do antycypowania przyszłych decyzji władzy monetarnej, a w konsekwencji - czy pomaga bankom centralnym w ukształtowaniu się cen aktywów finansowych na pożądanym poziomie ${ }^{33}$. W opisywanym przykładzie analizie poddano tylko i wyłącznie wypowiedzi członków komitetów monetarnych pomiędzy poszczególnymi posiedzeniami. Wyniki, które uzyskali, potwierdziły postawioną przez nich hipotezę. Mianowicie przewidywalność decyzji FOMC oraz EBC w analizowanym okresie była wyższa niż w wypadku Banku Anglii. Potwierdzono także tezę, że komunikacja banku centralnego jest ekonomicznie i statystycznie istotnym czynnikiem kształtującym zachowania na rynku finansowym ${ }^{34}$. Ponadto podobnie jak w innych badaniach wykazano, że w wypadku FOMC rynek znacznie mocniej reagował na wypowiedzi Greenspana niż pozostałych członków, natomiast w wypadku EBC reakcje na słowa prezesa oraz pozostałych przedstawicieli rady były podobne (wynika to zapewne z kolegialnego trybu podejmowania decyzji).

${ }^{30}$ Ibidem, s. 22.

${ }^{31}$ R. Reeves, M. Sawicki, Do Financial Markets React to Bank of England Communication?, „European Journal of Political Economy” 23, 2007, s. 207-227.

${ }^{32}$ M. Ehrmann, M. Fratzscher, Communication by Central Bank Committee Members: Different Strategies, Same Effectiveness?, ,Journal of Money, Credit and Banking” 39, 2007, nr 2-3, s. 509-41.

${ }^{33}$ Ibidem, s. 511.

34 Ibidem. 
Rozkrut $^{35} \mathrm{w}$ jednej ze swoich prac analizował wpływ wypowiedzi członków Rady Polityki Pieniężnej w sprawie przyszłej polityki pieniężnej oraz nadchodzącej sytuacji gospodarczej na kształtowanie się cen na rynku finansowym. Wykazał, że tego typy wiadomości wpływały znacząco zarówno na stopy o krótkim, jak i dłuższym terminie zapadalności. Natomiast na komunikaty NBP w sprawie przyszłych zmian polityki pieniężnej reagowały przede wszystkim instrumenty 2- i 5-letnie. Ponadto autor wykazał w swojej pracy, że wypowiedzi członków RPP pomiędzy poszczególnymi posiedzeniami zwiększały przewidywalność decyzji.

\subsection{Jakość i jasność przekazywanych informacji}

Niektóre badania próbowały uchwycić różnice w stosowaniu dwóch rodzajów narzędzi używanych do przekazywania przez bank centralny wniosków płynących z posiedzenia komitetu monetarnego:

- w pierwszej kolejności badano, jak opublikowanie decyzji dotyczącej poziomu głównych stóp procentowych wpływa na zachowania uczestników rynku;

- następnie analizowano, jak konferencja prasowa, na której wyjaśniano decyzje oraz ich motywy, oddziałuje na ceny i ich zmienność na rynku finansowym.

Ehrmann i Fratzscher ${ }^{36}$ w jednej ze swoich prac na przykładzie EBC, który to publikuje swoją decyzję na 45 minut przed konferencją prasowa, wykazali, że konferencja prasowa ma znacznie większy wpływ na rynkowe stopy procentowe niż ogłoszenie samego komunikatu. Zauważyli oni także, iż większemu wpływowi nie towarzyszy zwiększona zmienność, co oznacza, że rynek reaguje na konferencję prasową, ponieważ otrzymuje nowe informacje, a nie jest pełen szumu informacyjnego.

A. Fracasso, G. Genberg i Ch. Wyplosz ${ }^{37}$ stworzyli subiektywne wskaźniki oceny jakości raportów inflacyjnych w 19 krajach. Okazało się, że wyższej jakości dokumentów towarzyszyła mniejsza niepewność na rynku finansowym.

P. Gerlach-Kristen ${ }^{38}$ podjęła próbę zbadania, czy przejrzystość banku centralnego Anglii zwiększała się w wyniku publikacji minutes, których jednym z bardzo ważnych elementów jest rozkład wyników głosowania. Celem badania było sprawdzenie, czy znajomość rozkładu głosów dostarcza uczestnikom rynku finansowego nowych informacji w zakresie przyszłych decyzji MPC, a także czy te nowe informacje wpływaja na kształtowanie się oczekiwań rynkowych. Uzyskane rezultaty pokazały, że publikacja rozkładu głosów komitetu monetarnego Banku Anglii dostarcza informacji nieznanych wcześniej uczestnikom

${ }^{35}$ M. Rozkrut, op. cit.

${ }^{36}$ M. Ehrmann, M. Fratzscher, Explaining Monetary Policy Decisions in Press Conference, ECB Working Paper 767, 2007.

${ }^{37}$ A. Fracasso, G. Genberg, Ch. Wyplosz, How Do Central Bank Write? An Evaluation of Inflation Targeting Central Banks, Geneva Reports on the World Economy Special Report, vol. 2, 2003.

${ }^{38}$ P. Gerlach-Kristen, Is the MPC's Voting Record Informative about Future UK Monetary Policy, „Scandinavian Journal of Economics” 106, 2004, nr 2, s. 299-313. 
życia gospodarczego. Jeśli w mniejszości w stosunku do reszty komitetu są członkowie MPC głosujący za obniżeniem stopy repo, to jest bardziej prawdopodobne, że na kolejnym spotkaniu stopy będą obniżane niż podwyższane. Dlatego też - zdaniem Gerlach-Kristen ${ }^{39}$ - wiedza na temat liczby osób niezgadzających się z podejmowaną przez większość członków decyzja umożliwia przewidywanie przyszłych decyzji. Ponadto na podstawie analizy zachowania się krzywej dochodowości, wykazała ona, że oczekiwania rynkowe reaguja na publikację minutes, co potwierdza, iż ten przekaz zawiera nowe informacje, które nie były znane rynkowi po ogłoszeniu samej decyzji o zmianie stopy dwa tygodnie wcześniej.

Warto również przywołać rozległe badania przeprowadzone w 2003 i 2004 r. przez E. Connolly'ego i M. Kohlera. Jednym z celów ich analizy było udzielenie odpowiedzi na pytanie, który z kanałów komunikacji ma największy wpływ na kształtowanie się oczekiwań dotyczących przyszłych działań podejmowanych przez bank centralny. Ich zdaniem ocena wpływu komunikacji polityki monetarnej na oczekiwania rynku finansowego w sprawie przyszłych stóp procentowych powinna być dokonywana $\mathrm{w}$ świetle także innych czynników wewnętrznych i zewnętrznych, które znacznie bardziej moga wpływać na te oczekiwania. Do tych pozostałych zmiennych należą: krajowe dane makroekonomiczne, informacje z zagranicy oraz efekt zaskoczenia wynikający z działań banku centralnego ${ }^{40}$. Wpływ tych czterech zmiennych na dzienne zmiany w kształtowaniu się kontraktów futures na stopy procentowe szacowali oni za pomocą modelu EGARCH dla sześciu banków centralnych (Australia, Kanada, strefa euro, Nowa Zelandia, Wielka Brytania, Stany Zjednoczone). Okres badawczy obejmował lata 1999 - czerwiec 2004. Okazało się, że oczekiwane stopy procentowe reagują zarówno na dane makroekonomiczne, jak i informacje wysyłane różnymi kanałami komunikacyjnymi przez banki centralne. Autorzy podkreślaja, że oczekiwane stopy procentowe reaguja znacznie silniej na dane makroekonomiczne oraz informacje $\mathrm{z}$ zagranicy. Choć zauważony wpływ polityki komunikacyjnej był mały, to zaobserwowano, że odchylenie standardowe w dniu pojawienia się komunikatu banku centralnego rosło. Wśród wielu narzędzi wykorzystywanych przez banki centralne i poddanych analizie największe znaczenie miały: komentarze po podjętych decyzjach $\mathrm{w}$ sprawie podstawowych stóp procentowych, publikowane raporty na temat polityki pieniężnej oraz przesłuchania parlamentarne.

A. Sirchenko ${ }^{41} \mathrm{w}$ swojej pracy na przykładzie polityki prowadzonej przez Narodowy Bank Polski wykazał, że wiedza uczestników rynku na temat rozkładu głosów przed kolejnym posiedzeniem RPP (szczególnie na temat, kto głosował przeciwnie do ostatecznej decyzji Rady) ma dużą wartość informacyjna. Zdaniem autora publikacja wyników głosowań przez NBP znacznie wcześniej zwiększyłaby przewidywalność decyzji RPP. Można jednak spotkać się z poglądami, że publikacja rozkładu głosów w możliwie szybkim terminie ma

\footnotetext{
39 Ibidem, s. 312.

${ }^{40}$ E. Connolly, M. Kohler, News and Interest Rate Expectations: A Study of Six Central Banks, Research Discussion Paper 2004-10, Economic Group Reserve Bank of Australia, 2004, s. 1.

${ }^{41}$ A. Sirchenko, Policymakers' Votes and Predictability of Monetary Policy, http://escholarship. org/uc/item/8qj3z3qg\#page-1, 2010.
} 
znaczenie w wypadku komitetów monetarnych podejmujących decyzje w sposób indywidualistyczny, czyli każdy z członków występuje publicznie w swoim imieniu, a nie w imieniu ciała decyzyjnego o charakterze kolegialnym.

\section{Przykłady indeksów mierzących stopień przejrzystości polityki pieniężnej}

Jedną z pierwszych prac poświęconych udokumentowaniu praktyk dotyczących przejrzystości polityki monetarnej w 94 bankach centralnych napisali M. Fry, L. Mahadeva, S. Roger i G. Sterne ${ }^{42}$. Skonstruowali oni indeks nazwany policy explanations - polityka wyjaśnień, na który składały się trzy komponenty: 1) explanations of policy decisions - wyjaśnianie podejmowanych decyzji, 2) explanations in forecasts and forward-looking analysis - wyjaśnienia zawarte $\mathrm{w}$ analizach prognostycznych, 3) explanations in published assessments and research - wyjaśnienia zawarte $\mathrm{w}$ publikowanych badaniach. W każdej z tych kategorii postawiono po kilka pytań, do których przypisano stosowną wagę oraz punktację. W wyniku tego badania powstała lista banków, które charakteryzowały się określonym stopniem przejrzystości. Oszacowany wskaźnik przejrzystości dla Polski w 2000 r. wynosił 69 punktów i znajdował się poniżej średniej dla krajów ze strategia celu inflacyjnego. Podobną kalkulację na podstawie tego indeksu dla 2005 r. przeprowadzili T. Łyziak, J. Mackiewicz i E. Stanisławska ${ }^{43}$ - wtedy ten indeks wyniósł już 85, co wynikało ze zmian $\mathrm{w}$ polityce komunikacyjnej wprowadzonej po $2003 \mathrm{r}$.

Nazwiskami, które nieodłącznie związane sa z tematyką przejrzystości polityki pieniężnej, są Eijffinger oraz Geraats. W pracy How Transparent Are Central Banks sporządzili oni indeks, który oparty został na szczegółowej analizie informacji ujawnianych przez dziewięć głównych banków centralnych ${ }^{44}$. Koncepcja ich badania oparta została na pięciu typach przejrzystości zaproponowanych przez Geraats. Opracowany indeks mierzący transparentność składał się z pięciu subindesków odpowiadających każdemu typowi przejrzystości. W ramach każdego z subindeksów postawiono po trzy pytania, przypisano każdemu z nich taką samą wagę. Za każde z postawionych pytań można było przyznać maksymalnie 1 punkt. Końcową miarą określającą stopień transparentności była suma piętnastu odpowiedzi, dająca maksymalnie piętnastu punktów. Swoje badanie rozpoczęli oni od wyszukania informacji publikowanych przez banki centralne, które dostępne były w języku angielskim. Następnie uzyskane wyniki, wraz ze szczegółowym opisem indeksu przejrzystości, przesłali do każdego z banków z prośbą o przejrzenie. Trzecim krokiem była ponowna ocena na podstawie uwag banków centralnych.

\footnotetext{
${ }^{42}$ M. Fry, L. Julius, L. Mahadeva, S. Roger, G. Sterne, Key Issues in the Choice of Monetary Policy Framework, w: L. Mahadeva, G. Sterne (red.), Monetary Frameworks in a Global Context, Routledge, London 2000, s. 1-216.

${ }^{43}$ T. Łyziak, J. Mackiewicz, E. Stanisławska, Central Bank Transparency and Credibility: The Case of Poland, 1998-2004, „European Journal of Political Economy” 23, 2007, s. 76-78.

${ }^{44}$ S. C. Eijffinger, P. M. Geraats. Badanie to zostało bardzo szczegółowo opisane, ponieważ w kolejnych latach wiele analiz opierało się na tej właśnie procedurze badawczej.
} 
W ramach każdego z pięciu typów przejrzystości ocenie poddawano następujące kwestie $^{45}$ :

a) przejrzystość ustawowa:

- sposób sformułowania celu polityki pieniężnej - brano pod uwagę, czy cel był jeden, czy też kilka ( $w$ tym wypadku, czy poddane były one hierarchizacji według kryterium ważności celu),

- ilościowe określenie celu polityki monetarnej,

- istnienie instytucjonalnej umowy pomiędzy bankiem centralnym a rządem, przyjmującej najczęściej formę określającą instytucjonalną niezależność władzy monetarnej;

b) przejrzystość ekonomiczna:

- publikacja kwartalnych danych gospodarczych dotyczących ważnych dla polityki monetarnej: podaż pieniądza, wskaźnik inflacji, PKB, stopa bezrobocia,

- model wykorzystywany przez bank centralny do prowadzenia polityki pieniężnej,

- publikacja wewnętrznych prognoz wzrostu gospodarczego i inflacji przez bank centralny;

c) przejrzystość proceduralna:

- przedstawianie jako podstawy swoich działań określonej strategii polityki pieniężnej, czy też zasad, na podstawie których sa podejmowane decyzje,

- publikacja tzw. minutes w odpowiednim czasie,

- publikacja rozkładu głosów dotycząca podejmowanych decyzji (voting records);

d) przejrzystość polityczna:

- ogłaszanie podjętych decyzji w stosownym czasie,

- wyjaśnianie podjętej decyzji w trakcie jej ogłoszenia,

- publikacja skłonności banku centralnego dotyczących przyszłych decyzji banku centralnego;

e) przejrzystość operacyjna:

- regularne dokonywanie oceny, w jakim zakresie udało się bankowi centralnemu osiągać swój cel operacyjny,

- regularne dostarczanie informacji na temat występowania nieoczekiwanych zakłóceń $\mathrm{w}$ otoczeniu gospodarczym wpływających na proces mechanizmu transmisji,

- regularne dokonywanie ewaluacji osiaganych wyników w świetle celów makroekonomicznych.

Okazało się, że w okresie badawczym 1998-2002 najbardziej transparentnymi bankami centralnymi były instytucje monetarne z Nowej Zelandii, Szwecji oraz Wielkiej Brytanii. W dalszej kolejności były to: Bank Kanady, Europejski Bank Centralny oraz Rezerwa Federalna USA. Najmniejszą przejrzystościa z kolei charakteryzowały się banki centralne: Australii, Japonii oraz Szwajcarii. Autorzy zauważyli, że grupa najbardziej transparentnych krajów realizowała politykę pieniężną zgodnie ze strategia bezpośredniego celu inflacyjnego. Analiza powyższych danych wskazuje wyraźnie, że poszczególne banki centralne przykładają różną wagę do poszczególnych typów przejrzystości. Eij-

${ }^{45}$ Ibidem, s. 6-11. 


\section{Wykres 2}

Indeks przejrzystości dla wybranych banków centralnych (stan na czerwiec 2002 r.)

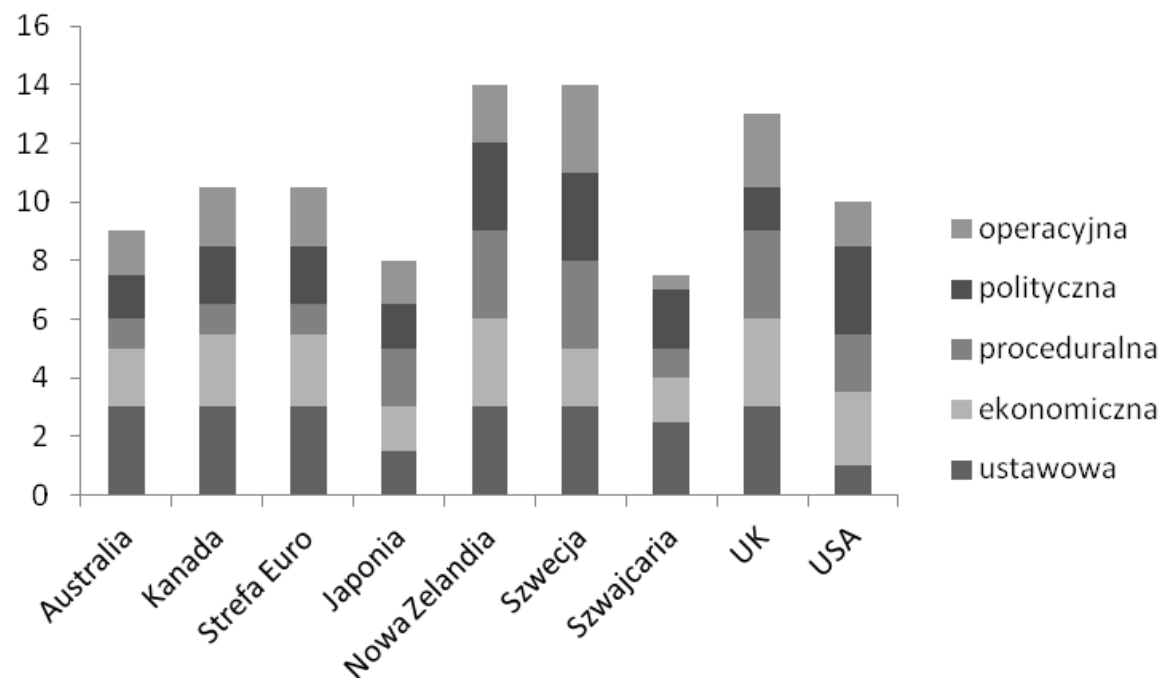

Źródło: S. C. Eijffinger, P. M. Geraats, How Transparent Are Central Banks?, January 2005, s. 26.

ffinger oraz Geraats zwracają w swoich wnioskach szczególną uwagę na dwa banki: FED oraz EBC. Osiagnęły one podobny stopień przejrzystości, z tym że EBC uzyskał maksymalną liczbę 3 punktów za przejrzystość ustawową (FED tylko 1), z kolei FED wyróżnia się transparentnością polityczną, czyli odpowiednim ogłaszaniem swoich decyzji, wyjaśnianiem ich oraz właściwym określaniem prawdopodobnych działań w przyszłości. Warto w tym miejscu wspomnieć, że prowadzone badania, w których analizuje się, w jaki sposób rynki finansowe reagują na decyzje ogłaszane przez FED oraz przez EBC, wskazują, $i \dot{z}$ to FED jest bardziej przewidywalnym, a dzięki temu transparentnym bankiem.

Wskazana powyżej metodologia była m.in. wykorzystana w badaniu przeprowadzonym przez N. Dincera i B. Eichengreena ${ }^{46}$. Opierając się na indeksie składającym się z 15 subindeksów oraz danych zaczerpniętych ze stron internetowych banków centralnych, a także ze: statutów, raportów rocznych oraz innych opublikowanych dokumentów, dokonali oni oceny stopnia przejrzystości w 100 bankach centralnych w okresie 1998-2006 ${ }^{47}$. Ich badanie potwierdza w części wyniki uzyskane przez Eijffingera oraz Geraatsa ${ }^{48}$. W $2006 \mathrm{r}$. najbardziej transparentną polityką monetarną prowadziły banki centralne Nowej Zelandii, Szwecji, Anglii, Kanady, a także Czech, Węgier oraz EBC.

\footnotetext{
${ }^{46}$ N. Dincer, B. Eichengreen, Central Bank Transparency: Causes, Consequences and Updates, NBER, Working Paper 14791, 2009.

47 Ibidem, s. 7.

${ }^{48}$ S. C. Eijffinger, P. M. Geraats, op. cit.
} 
Z kolei najmniej przejrzystymi bankami centralnymi okazały się być banki z Aruby, Etiopii, Libii i Arabii Saudyjskiej. Przeprowadzona analiza wykazała, że w żadnym ze 100 krajów nie zmniejszył się indeks przejrzystości podczas analizy. Ponadto podobnie jak w innych badaniach potwierdzono, że banki centralne $\mathrm{w}$ krajach rozwiniętych sa bardziej transparentne niż $\mathrm{w}$ krajach wschodzących.

W drugiej części badania autorzy starali się odpowiedzieć na pytanie, jakie czynniki odpowiadają za istnienie różnic $\mathrm{w}$ zakresie stopnia przejrzystości w poszczególnych krajach poddanych analizie. W tym celu szacowali oni równanie, w którym zmiennymi objaśniającymi były m.in.: PKB per capita, wskaźnik inflacji, reżim kursowy, a także takie zmienne, jak: zasady prawne obowiązujące w danym kraju, stabilność polityczna, stopień demokratyzacji państwa. Autorzy podkreślali szczególnie silny związek pomiędzy stopniem przejrzystości a PKB per capita. Zauważono, że płynny kurs walutowy jest także czynnikiem poprawiającym indeks przejrzystości. Większość tzw. zmiennych politycznych okazała się istotnie wpływać na transparentność polityki monetarnej. W kolejnym kroku podjęto próbę zbadania, który z powyższych czynników z osobna wpływa na każdy z pięciu typów przejrzystości. O ile poziom PKB oraz płynność kursu walutowego były pozytywnie skorelowane z każdym ze wspomnianych typów, o tyle poszczególne czynniki polityczne w różnym stopniu wpływały na każdy z rodzajów przejrzystości.

\section{PODSUMOWANIE}

Banki centralne na całym świecie podkreślaja bardzo mocno znaczenie przejrzystości w prowadzeniu polityki pieniężnej. Odpowiednia polityka komunikacyjna to kluczowy czynnik, który pzwala władzy monetarnej wpływać na ceny aktywów finansowych, a w konsekwencji na kształtowanie oczekiwań rynkowych oraz osiagganie celów strategicznych. Studia literaturowe przeprowadzone przez autorkę na potrzeby niniejszej pracy dowiodły, że nie został jeszcze ustalony wspólny konsensus $\mathrm{w}$ zakresie optymalnego stopnia transparentności polityki pieniężnej. W zależności od gospodarki i sposobu prowadzenia polityki pieniężnej liczba używanych instrumentów polityki komunikacyjnej jest różna. Nie ulega jednak wątpliwości, że żaden $\mathrm{z}$ banków centralnych nie ograniczył liczby stosowanych narzędzi polityki komunikacyjnej. Jak wykazali w swoim badaniu Dincer oraz Eichengreen ${ }^{49}$, w 2006 r. 89 banków na 100 charakteryzowało się rosnącym indeksem przejrzystości i, co ważne, żaden z nich nie cechował się obniżającym się indeksem przejrzystości, wręcz przeciwnie - można zaobserwować ciągła poprawę w tym obszarze.

Odpowiednia polityka komunikacyjna stała się bardzo ważnym narzędziem polityki pieniężnej. Potwierdzaja to liczne badania prowadzone na całym świecie, na podstawie których można wyciągnąć następujące wnioski.

${ }^{49}$ N. Dincer, B. Eichengreen, op. cit. 
Po pierwsze, poprawianie komunikacji z otoczeniem gospodarczym wpływa pozytywnie na przewidywalność działań komitetów monetarnych, co oznacza, że uczestnicy rynku finansowego coraz lepiej rozumieją sposób postępowania banków centralnych. W znacznej części badań potwierdzono pozytywny wpływ przejrzystości polityki pieniężnej na zmniejszenie zmienności stóp rynkowych w dniu posiedzeń komitetu monetarnego, co dowodzi faktu, że właściwa komunikacja poprawia właściwe odczytywanie intencji banku centralnego w zakresie przewidywalności jego decyzji. Poprawne odczytywanie intencji banku centralnego przekłada się także na kształtowanie się oczekiwań długoterminowych, m.in. w obszarze oczekiwań inflacyjnych, co z kolei jest bardzo ważne $\mathrm{z}$ punktu widzenia skuteczności banku centralnego $\mathrm{w}$ realizacji strategicznego celu polityki pieniężnej.

Po drugie, zauważono, że dla uczestników rynku nie tylko ważna jest sama decyzja na temat zmiany podstawowych stóp procentowych, ale przede wszystkim oczekuja oni na konferencję prasowa, na której przedstawiciele komitetu monetarnego wyjaśnią motywy swoich działań oraz wpływ na przyszłość. Konferencje prasowe zawierają w sobie istotną dodaną wartość informacyjną.

Po trzecie, wykazano, że wypowiedzi członków komitetów monetarnych pomiędzy poszczególnymi posiedzeniami wpływają pozytywnie na przewidywalność decyzji. Co oznacza, że banki centralne nie powinny unikać kontaktu z rynkiem, oczywiście w odpowiednim czasie i w odpowiedniej formie. Większość badań potwierdza także, że odpowiednio dobrana forma przekazu redukuje chaos informacyjny i wpływa na poprawę efektywności prowadzonej polityki.

Dużo miejsca w najnowszych badaniach poświęcono znaczeniu publikacji minutes wraz z rozkładem głosów oraz raportów o inflacji dla poprawy polityki komunikacyjnej banku centralnego. W wypadku raportów o inflacji potwierdza się, że ich opublikowanie niesie za sobą odpowiednią wartość informacyjną. Stworzone zostały wskaźniki oceny jakości tych dokumentów ${ }^{50}$, na podstawie których wykazano, że wyższej jakości dokumentów towarzyszyła mniejsza niepewność na rynku finansowym. Wnioski płynące z badań poświęconych wpływowi minutues oraz voting records na poprawę przejrzystości polityki niestety nie sa już tak jednoznaczne. Zdaniem części badaczy wiedza na temat liczby osób niezgadzających się $\mathrm{z}$ podejmowaną przez większość członków decyzją umożliwia przewidywanie przyszłych decyzji. Ponadto zmiany w kształcie i położeniu krzywej dochodowości oznaczaja, że oczekiwania rynkowe reagują na publikację minutes, co potwierdza, iż ten przekaz zawiera nowe informacje, które nie były znane rynkowi po ogłoszeniu samej decyzji o zmianie stóp. Jednakże jest również grupa badań wykazujących, że w wypadku banków centralnych, w których decyzje podejmowane sa kolegialnie, publikacja rozkładu głosów jest bezcelowa.

Inną, jeszcze bardziej dyskusyjną kwestia jest włączenie do optymalnego zestawu instrumentów polityki komunikacyjnej publikacji prognoz ścieżki stóp procentowych. W tym obszarze głosy są bardzo podzielone. Zwolennicy uważaja,

${ }^{50}$ A. Fracasso, G. Genberg, Ch. Wyplosz, op. cit. 
że podobnie jak prognozy inflacji oraz wzrostu gospodarczego, tak prognoza stóp procentowych poprawiłaby przewidywalność i skuteczność działań banku centralnego. Przeciwnicy wykazuja, że w razie rozbieżności pomiędzy aktualnym a prognozowanym poziomem stóp procentowych mogą wystapić negatywne reakcje rynku wpływające na postrzeganie wiarygodności polityki monetarnej.

dr Urszula Ziarko-Siwek

Uniwersytet Ekonomiczny w Poznaniu

\title{
TRANSPARENCY OF THE MONETARY POLICY IN THEORETICAL AND EMPIRICAL STUDIES
}

\begin{abstract}
Summary
This paper aims to review the existing body of research, both theoretical and empirical, conducted in the last fifteen years on the transparency and communication policies of central banks. In the first section, selected definitions of the transparency of the a monetary policy proposed in leading academic papers on the topic are presented. Further sections present a set of instruments which can improve the communication policy. The last section presents the most important research conducted in the last decade or so in Poland and abroad with the main objective of determining the relationship between a transparent monetary policy and the development of prices and expectations of the financial market. Particular emphasis was placed on research aimed at comparing different economies in terms of transparency of their monetary policies using transparency indices specifically developed for this purpose.
\end{abstract}


Copyright of Journal of Law, Economics and Sociology is the property of Faculty of Law and Administration of Adam Mickiewicz University in Poznan and its content may not be copied or emailed to multiple sites or posted to a listserv without the copyright holder's express written permission. However, users may print, download, or email articles for individual use.

Właścicielem praw autorskich do „Ruchu Prawniczego, Ekonomicznego i Socjologicznego” jest Wydział Prawa i Administracji Uniwersytetu im. Adama Mickiewicza w Poznaniu. Zawartość czasopisma nie może być kopiowana, przesyłana do innych stron internetowych bądź zamieszczana na blogach bez pisemnej zgody wydawcy. Niemniej artykuły można drukować, kopiować lub przesyłać w formie elektronicznej na własny użytek. 